\title{
触 New Disease Reports \\ First report of Polerovirus of the family Luteoviridae infecting cotton in India
}

A.K. Mukherjee*, P.R. Chahande, M.K. Meshram and K.R. Kranthi

Division of Crop Protection, Central Institute for Cotton Research, Post Box No. 2, Shankar Nagar, Nagpur 440010, Maharashtra, India

*E-mail: titirtua@gmail.com

Received: 31 Dec 2011. Published: 25 Apr 2012. Keywords: Cotton leafroll dwarf virus (CLRDV), viral disease of cotton

Cotton blue disease caused by Cotton leaf roll dwarf virus (CLRDV, Genus: Polerovirus, Family: Luteoviridae) is a serious problem in cotton cultivation in South America causing yield losses up to $80 \%$ in susceptible varieties (Silva et al., 2008; Distéfano et al., 2010). This positive-sense, single-stranded RNA virus is transmitted by aphids (Aphis gossypii) in a circulative-persistent manner. It can spread very fast and is difficult to control. So far, this disease has not been reported from India. Cotton plants affected by this disease show stunting, leaf rolling, intense green foliage, vein yellowing, brittleness of leaves, reduced flower and boll size, sometimes resulting in sterility of plants (Fig. 1).

Leaf samples from plants with symptoms suggestive of CLRDV and apparently healthy plants were collected from cotton fields (Nagpur, Maharashtra, India) and washed with RNase-free sterile double distilled water before total RNA isolation. RNA was extracted from leaf samples (100 mg) using Spectrum Plant Total RNA kit (Sigma USA). RT- PCR was performed using Qiagen OneStep RT- PCR kit (Qiagen, USA) following the manufacturers' instructions with the primers PL4F(5'-GCGACAAATAGTTAATGAATACGGT-3') and o3R (5'-GTCTACCTATTTBGGRTTNTGGAA-3'). The primers were designed to amplify a region of approximately $600 \mathrm{bp}$ of the capsid protein sequence of CLRDV (Corrêa et al., 2005). PCR conditions were: denaturation at $94^{\circ} \mathrm{C}$ for $45 \mathrm{~s}$, primer annealing at $49^{\circ} \mathrm{C}$ for $45 \mathrm{~s}$, extension at $72^{\circ} \mathrm{C}$ for 45 $\mathrm{s}$ for 35 cycles and final extension at $72^{\circ} \mathrm{C}$ for $10 \mathrm{~min}$. PCR from symptom-bearing samples resulted in the amplification of a $600 \mathrm{bp}$ band which is the expected size (Fig. 2). PCR from healthy samples did not produce an amplicon. The PCR products were sequenced directly and the resulting sequence was deposited at GenBank (Accession No. JN033875) The coat protein sequences derived from the PCR products from
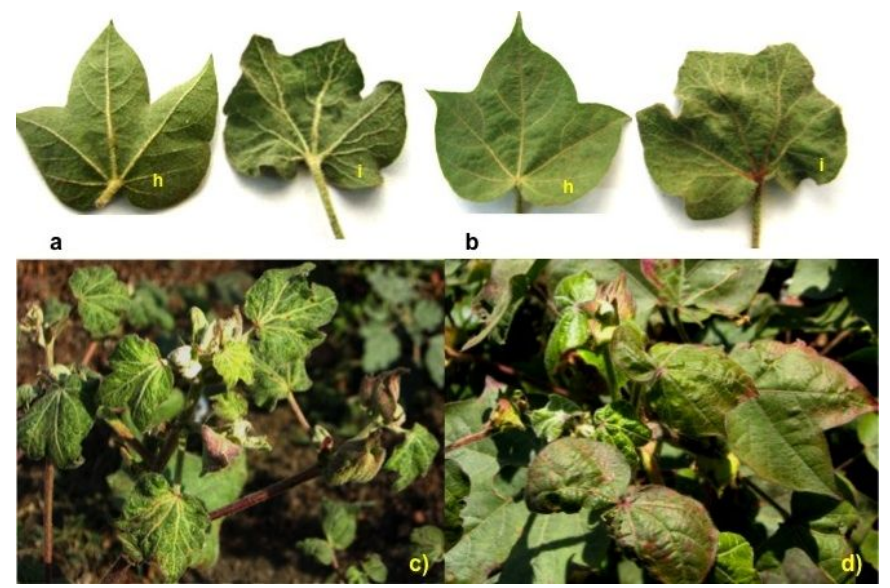
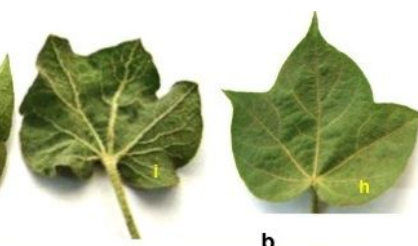

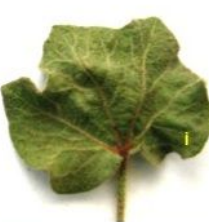

symptom-bearing plants showed more than $90 \%$ similarity with Cotton leaf roll dwarf virus and Chickpea stunt virus (another member of Polerovirus) as reported by earlier workers (Corrêa et al., 2005; Silva et al., 2008; Distefano et al., 2010). This is the first report of the detection of a Polerovirus infecting cotton in India.

\section{References}

Corrêa RL, Silva TF, Simões-Araújo JL, Barroso PAV, Vidal MS, Vaslin MFS, 2005. Molecular characterization of a virus from the family Luteoviridae associated with cotton blue disease. Archives of Virology 150, 1357-1367. [doi:10.1007/s00705-004-0475-8]

Distéfano AJ, Kresic IB, Hopp HE, 2010. The complete genome sequence of a virus associated with cotton blue disease, cotton leafroll dwarf virus, confirms that it is a new member of the genus Polerovirus. Archives of Virology155, 1849-1854. [doi:10.1007/s00705-010-0764-3]

Silva TF, Corrêa RL, Castilho Y, Silvie P, Bélot JL, Vaslin MFS, 2008. Widespread distribution and a new recombinant species of Brazilian virus associated with cotton blue disease. Virology Journal 5, 123. [doi: $10.1186 / 1743-422 X-5-123$ ]

Figure 1
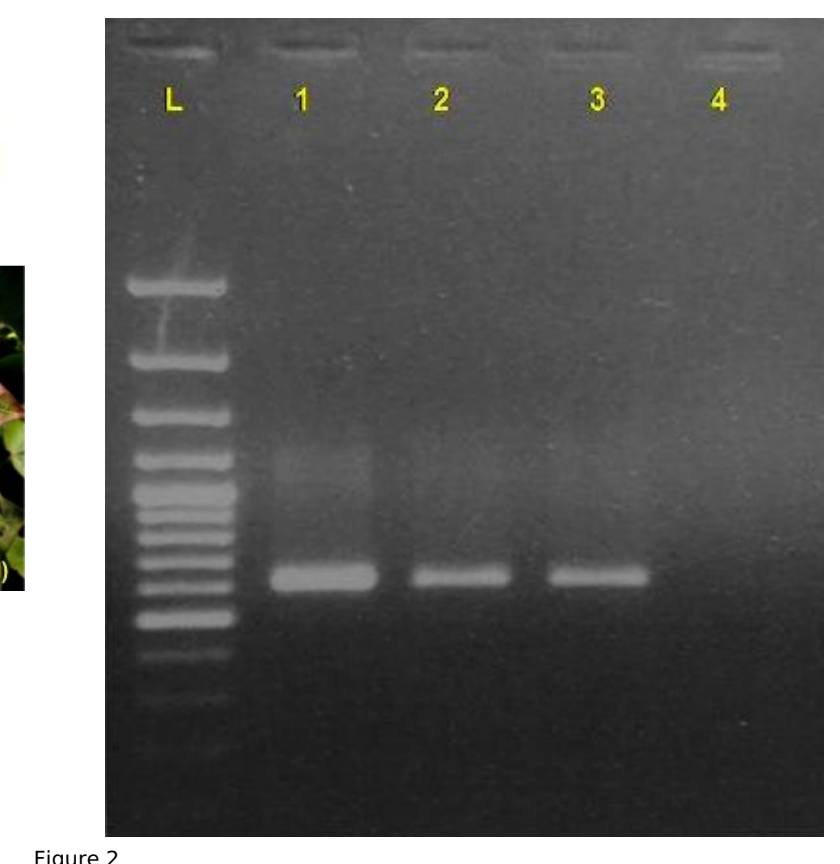

Figure 2

To cite this report: Mukherjee AK, Chahande PR, Meshram MK, Kranthi KR, 2012. First report of Polerovirus of the family Luteoviridae infecting cotton in India. New Disease Reports 25, 22. [doi:10.5197/j.2044-0588.2012.025.022]

(c) 2012 The Authors

This report was published on-line at www.ndrs.org.uk where high quality versions of the figures can be found. 